\title{
Morphological Characterization of Grapefruit and Pummelo Accessions Using the ISSR Molecular Markers
}

Fatma K. Ahmed", A. A. E-Homosany ${ }^{* *}$ and H. A. Sayed ${ }^{* *}$ *Citrus Research Department, Horticulture Research Institute and ${ }^{* *}$ National Gene Bank and Genetic Resource (NGBGR), Agricultural Research Centre, Cairo, Egypt.

\begin{abstract}
MONG the national objectives of the National Gene Bank and Genetic Resources (NGBGR) in Egypt are the collection, characterization, evaluation and conservation of agricultural genetic resources. On the other hand the main goal of Horticulture Research Institute is to enhance the productivity of horticultural crops in quantity and quality. The present study investigates the morphological characterization and estimates the genetic polymorphism and relationships among 9 citrus cultivars (4 grapefruit and 5 pummelo) accessions based on ISSR markers. Twenty- eight morphological characteristics were studied to describe the tree, leaf, inflorescence, fruits and seeds. The morphological characterization showed wide range of differences among grapefruit and pummelo accessions. Characterization of leaf lamina shape resulted in five accessions having ovate shape, three were Elliptic and one was orbicular. Fruit shape studies indicated that three accessions (Ruby red, Moneybi and Egy ptian) were obloid, five (Marsh, White, Rabehe, Gizawe and Broad leaf) were spheroid and one (Duncan) was pyriform. Shape of fruit apex demonstrated that four accessions were truncate, four were depressed, and one was rounded. Differences in flavido (rind skin) colour among accessions revealed that one cultivar was pink - yellow, two were green-yellow, one was dark yellow and the rest of the accessions were yellow. Meanwhile, flesh colour was white in 12169 , 12171 and12173, light yellow in 12172, yellow in 12167 and 12168 , pink in 12170, light red in 12166 and red in 12174 flesh.
\end{abstract}

Inter-simple sequence repeats (ISSR) markers were used to study the genetic diversity and phylogenetic relationships among four grapefruit (Citrus paradise), five pummelo (Citrus maxima) accessions. Thirteen ISSR primers produced the total number of amplified amplicons among tested primers ranging from 7 to 18 fragments. The highest number of fragments was 18 bands for $(\mathrm{AG})_{8} \mathrm{YC}$ primer. While, $(\mathrm{GT})_{8} \mathrm{YC}$ primer generated the lowest number of amplicons ( 7 bands). The average number of fragments/primer was (11.5) and the size of these fragment ranged from $98-1500 \mathrm{bps}$. The percentage of polymorphism revealed by the different primers ranged from 29 to $83 \%$ with average of $54.9 \%$.

Keywords: Citrus maxima, Citrus paradise, Germplasm characterization, ISSR markers. 
Citrus production occupies an important share in the total area and fruit production in Egypt which grown on 541,723 feddans with the production of 4,098,590 tons in the year 2013 (Ministry of Agriculture, 2013). Besides, citrus is an extremely important crop world-wide. It is widely grown in most areas with suitable climates i.e tropical, subtropical and borderline subtropical/ temperate (Kahn et al., 2001). Egypt is one of the top 10 producers of orange in the world (FAO, 2012). The grapefruit $(C$. paradisi Macf.) was notified as a natural hybrid between pummelo (Citrus maxima (Burm.) Merr.) and sweet orange $(C$. sinensis $L$. Osb). It originates from Barbados in the Caribbean is lands and was first named as Citrus paradisi Macf. by James Macfedyan in 1837 (Scora et al., 1982 and Scora, 1988). Grapefruits are highly polyembryonic. Therefore, they are of a nuclear and mutation origin. Genetic variation among common grapefruit cultivars was reported to be very low due to their mutation origin (Fang et al., 1997 and Corazza-Nunes et al., 2002). The pummelo is native to tropical and subtropical regions in Asia and has been cultivated in China for over 2000 years (Corazza-Nunes et al., 2002 and Yong et al., 2006). Pummelo was reported as one of the three true citrus species by Barrett and Rhodes (1976) and most of the subsequent studies were in agreement with this statement (Federici et al., 1998, Nicolosi et al., 2000, Barkley et al., 2006 and Uzun et al., 2009). Pummelo (C. maxima, or formerly known as $C$. grandis) is a tropical fruit plant species originated from South East Asia, which in the western world is called as shaddock (Uzun and Yesiloglu, 2012).

Utilization of the morphological characteristics may be useful however regularly lacking in separation of nearly related cultivars. Then again, certain morphologically diverse variations may be phylogenetic nearly related. Likewise morphological characteristics are exceptionally affected by nature (Fang et al., 1998). Accordingly, utilizing morphological attributes, it can be hard to recognize numerous Citrus cultivars (Fang et al., 1997). Since morphological characters are just of restricted utilization and cy togenetically parameters are lengthy, exchange methodologies, including application of molecular markers, have now been progressively received to address the is sues in Citrus scientific categorization (Kumar et al., 2013). Contrasted with the morphological information, sub-atomic apparatuses give inexhaustible data are exceedingly proficient and are coldhearted to ecological components.

Molecular markers has provided an ideal means for identifying genotypes, estimation of relatedness between different accessions and following inheritance of economically important characters.

Maximum utilization of any germplasm for breeding can be achieved by understanding the level of genetic diversity it contains (Vinu et al., 2013). Genetic diversity estimates are also important to understand its adaptive potential in different environments (Lowe et al., 2004). Evaluation of genetic divergence and relatedness among breeding materials has significant implications for crop improvements. The knowledge on genetic diversity in grapefruit and pummelo accessions could help breeders and geneticists to

Egypt. J. Hort. Vol. 42, No.1 (2015) 
understand the structure of germplasm and to predict which combination would produce the best offspring and facilitate in widening up the genetic basis of breeding material for selection (Singh, 2005). The present study investigates the morphological characterization, the genetic polymorphism and the relationships among grapefruit and pummelo accessions based on ISSR markers.

\section{Plant materials}

\section{Materials and Methods}

Plant materials used for this study were collected from Qalyubia governorate during 2012 and 2013 years. Four grapefruit and five pummelo accessions aged from $18-20$ years old trees planted at $3 \times 5 \mathrm{~m}$ in clay soil under flood irrigation and grown in Moshtohor Fac. of Agric. Res. Farm, Benha Univ., Egypt. (Table 1).

TABLE 1. List of plant materials Citrus species and cultivars used in this study .

\begin{tabular}{|c|c|c|}
\hline Accession number & Accession name & Scientific name \\
\hline 12166 & Ruby red & Citrus paradisi $\mathrm{L}$. \\
\hline 12167 & Duncan & Citrus paradisi $\mathrm{L}$. \\
\hline 12168 & Marsh & Citrus paradisi $\mathrm{L}$. \\
\hline 12169 & White & Citrus paradisi $\mathrm{L}$. \\
\hline 12170 & Moneybi & Citrus grandis, Osbeck \\
\hline 12171 & Rabehe & Citrus grandis, Osbeck \\
\hline 12172 & Gizawe & Citrus grandis, Osbeck \\
\hline 12173 & Egyptian & Citrus grandis, Osbeck \\
\hline 12174 & Broad leaf & Citrus grandis, Osbeck \\
\hline
\end{tabular}

\section{Molecular characterization}

Young leaves samples of four grapefruit and five pummelo accessions (Table 1) were used for this study.

DNA extraction and ISSR-PCR amplification conditions

Total genomic DNA was isolated using DNeasy Plant Mini Kit (Qiagen ${ }^{\circledR}$ Germany) according to the manual procedures. A total of 13 primers (Table 2) were used to amplify DNA fragments. These primers were selected after screening 30 different primers. PCR reaction was performed in $25 \mu$ reaction mix containing $1 \mathrm{X}$ PCR buffer, $2 \mathrm{mM} \mathrm{MgC1}{ }_{2}, 0.2 \mathrm{mM}$ of each dNTPs, $1 \mu \mathrm{M}$ oligonucleotide primer, $25 \mathrm{ng}$ genomic DNA and 1 unit of Taq DNA polymerase (Promega ${ }^{\circledR}$, USA). Amplification was performed in a 96-well BioRad $^{\odot}$ Thermal cycler (USA) under the following conditions: 3 min at $94^{\circ} \mathrm{C}$ for 1 cycle, followed by $1 \mathrm{~min}$ at $94^{\circ} \mathrm{C},(1 \mathrm{~min}$ at annealing temperature), and 2 min at $72^{\circ} \mathrm{C}$ for 35 cycles, and $7 \mathrm{~min}$ at $72^{\circ} \mathrm{C}$ for a final extension stage.

\section{Data analysis}

The banding patterns generated by ISSR primers were analyzed and compared to determine the genetic relatedness among different Citrus genotypes. The amplified fragments were scored either as present (1) or absent (0). The genetic 
similarity and similarity matrix among genotypes were estimated according to Dice coefficient (Sneath and Sokal, 1973). Dendrograms showing the genetic relationships were constructed using the Un-weighted Pair Group Method with Arithmetic Averages (UPGMA) by Phoretix 1D software (TotalLab, UK).

TABLE 2. List of primer names, sequences and annealing temperatures used in this study.

\begin{tabular}{|c|c|c|}
\hline Primer Name & Sequence & Annealing Temp. ${ }^{\circ} \mathrm{C}$ \\
\hline 5'Anchored repeats & & \\
\hline $\mathbf{P}_{16}$ & $\operatorname{ACG}(\mathbf{G T})_{7}$ & 50.0 \\
\hline 3'Anchored repeats & & \\
\hline $\mathrm{H}_{12}$ & $(\mathrm{GA})_{8} \mathrm{YT}$ & 41.0 \\
\hline $\mathrm{H}_{13}$ & $(\mathrm{GA})_{8} \mathrm{YC}$ & 42.5 \\
\hline $\mathrm{H}_{14}$ & $(\mathrm{GA})_{8} \mathrm{YG}$ & 44.0 \\
\hline $\mathrm{H}_{15}$ & $\mathrm{AG})_{8} \mathrm{YT}$ & 52.0 \\
\hline $\mathrm{H}_{16}$ & $(\mathrm{AG})_{8} \mathrm{YC}$ & 56.5 \\
\hline $\mathrm{H}_{17}$ & $(\mathrm{AG})_{8} \mathrm{YG}$ & 59.5 \\
\hline $\mathrm{H}_{21}$ & $(\mathrm{GT})_{8} \mathrm{YC}$ & 60.5 \\
\hline $\mathrm{H}_{29}$ & $(\mathrm{GACA})_{4} \mathrm{AT}$ & 41.5 \\
\hline $\mathrm{P}_{2}$ & $(\mathrm{CA})_{6} \mathrm{GG}$ & 48.0 \\
\hline $\mathrm{P}_{3}$ & $(\mathrm{CA})_{6} \mathrm{AC}$ & 42.5 \\
\hline $\mathrm{P}_{4}$ & $(\mathrm{GTG})_{3} \mathrm{GC}$ & 52.5 \\
\hline
\end{tabular}

$\mathrm{R}=$ purine, $\mathrm{Y}=\mathrm{p}$ y rimidine $(\mathrm{C}$ or $\mathrm{T}), \mathrm{B}=$ non- $\mathrm{A}, \mathrm{D}=$ non- $\mathrm{C}, \mathrm{H}=$ non- $\mathrm{G}, \mathrm{V}=$ non- $\mathrm{T}$

\section{Morphological characterization}

The morphological characteristics used to characterize and discriminate the 9 grapefruit and pummelo cultivars were based on those previously prescribed for Citrus by the International plant Genetic Resources Institute (IPGRI, 1999) taking into consideration all the precautions reported. In this respect, 17 quantitative and 13 qualitative morphological characteristics were selected for the present investigation. The study was performed using three trees for each cultivar, each tree was considered a replicate (Table 3). The present's traits were used for morphological characterization. Thirty mature and fully developed leaves per tree (mature leaves from one year old branches) were collected and characterized for leaf lamina length and width, ratio of leaf lamina length/width (leaf lamina shape), and petiole wings shape.

Data were recorded for flower pedicel length, number of petals per flower, petal length and width. All observations on the fruit and its related parts were made at the optimum maturity stage according to IPGRI, 1999. Fruit characteristics were observed on 10 typical fruits per each tree of the three replication trees. Data were documented for fruit weight, diameter, length and

Egypt. J. Hort. Vol. 42, No.1 (2015) 
shape. Records also included shape of fruit base and fruit apex, fruit rind skin colour, texture of skin surface and fruit rind thickness. The study comprised also number of segments per fruit, flesh colour, fruit axis and juice content in endocarp. Fully developed seeds were extracted from 10 fully ripened fruits taken from each tree of the three replications. In this respect, average number of seeds per fruit, seed shape, seed surface, seed length, seed width and seed weight were assessed.

TABLE 3. Code of morphological traits used in citrus accessions characterization.

\begin{tabular}{|c|c|c|c|}
\hline Code & Characters & & Character states \\
\hline \multicolumn{4}{|c|}{ 1. Qualitative Traits } \\
\hline L01 & Leaf lamina shape & \multicolumn{2}{|c|}{ (1)Ovate,(2)Elliptic,(3)Orbicular } \\
\hline L02 & Petiole wings shape & \multicolumn{2}{|c|}{ (1)Obdeltate,(2)Absent,(3)Obcordate } \\
\hline Fr03 & Fruit shape & \multicolumn{2}{|c|}{ (1)Oboid,(2)Pyriform,(3)Spheroid } \\
\hline Fr04 & Fruit skin colour & \multicolumn{2}{|c|}{$\begin{array}{l}\text { (1)Pink-y ellow,(2)Green- } \\
\text { yellow,(3)Yellow,(4)dark yellow }\end{array}$} \\
\hline Fr05 & Fruit skin texture & \multicolumn{2}{|c|}{ (1)Rough,(2)Smooth,(3)Pitted } \\
\hline Fr06 & Fruit flesh colour & \multicolumn{2}{|c|}{ (1)light red,(2)White,(3)Pink,(4)Yellow } \\
\hline Fr07 & Fruit axis & \multicolumn{2}{|c|}{ (1)Solid,(2)Semi-hollow,(3)Hollow } \\
\hline Fr08 & Fruit shape of base & \multicolumn{2}{|c|}{ (1)Concave,(2)Necked,( 3)Convex,(4)Truncate } \\
\hline Fr09 & Fruit shape of apex & \multicolumn{2}{|c|}{ (1)Truncate,(2)depressed,(3)Rounded } \\
\hline Fr010 & $\begin{array}{l}\text { Number of } \\
\text { segment/fruit }\end{array}$ & \multicolumn{2}{|c|}{ (1)[10-14],(2)[15-18] } \\
\hline S011 & $\begin{array}{l}\text { Number of } \\
\text { seed/fruit }\end{array}$ & \multicolumn{2}{|c|}{$(1)[5-9],(2)>50,(3)[20-50],(4)[10-19],(5)[1-4]$} \\
\hline \multicolumn{4}{|c|}{ 2. $\quad$ Quantitative Traits } \\
\hline $\begin{array}{lll}\text { L01 } \\
\end{array}$ & Leaf lamina length & Fr011 & Fruit rind thickness \\
\hline L02 & Leaf lamina width & Fr012 & Juice content/fruit \\
\hline L03 & Leaf ratio(L/W) & S013 & Seed Shape \\
\hline FL04 & $\begin{array}{l}\text { Flower pedicel } \\
\text { length }\end{array}$ & S014 & Seed surface \\
\hline FL05 & $\begin{array}{l}\text { Number of } \\
\text { petals/flower }\end{array}$ & S015 & Seed length \\
\hline FL06 & Petal length & S016 & Seed width \\
\hline FL07 & Petal width & S017 & Seed weight \\
\hline Fr08 & Fruit weight & & \\
\hline Fr09 & Fruit diameter & & \\
\hline Fr010 & Fruit length & & \\
\hline
\end{tabular}

\section{Statistical analysis}

The data of leaf, flower, fruit and seed characteristics were presented as mean $(n=30)$, and the means were compared using a one-way analysis of variance followed by Duncan's test at P 0.05 was considered statistically significant. 


\section{Results and Discussion}

Molecular characterization

Polymorphism detected by ISSR primers

ISSR amplification from all DNA samples of 4 grapefruit and 5 pummelo accessions (collected from Moshtohor region) produced prolific banding profiles for all 13 primers (Fig. 1). The total number of amplified amplicons among tested primers ranged from 7 to 18 fragments. 3'anchored $\mathrm{H}_{16}$ primer amplified the highest number of fragments (18 bands). While, $\mathrm{H}_{21}$ primer generated the lowest number of amplicons ( 7 bands). The average number of fragments/ primer was (11.5), and the size of these ranged from 98-1500 bps.
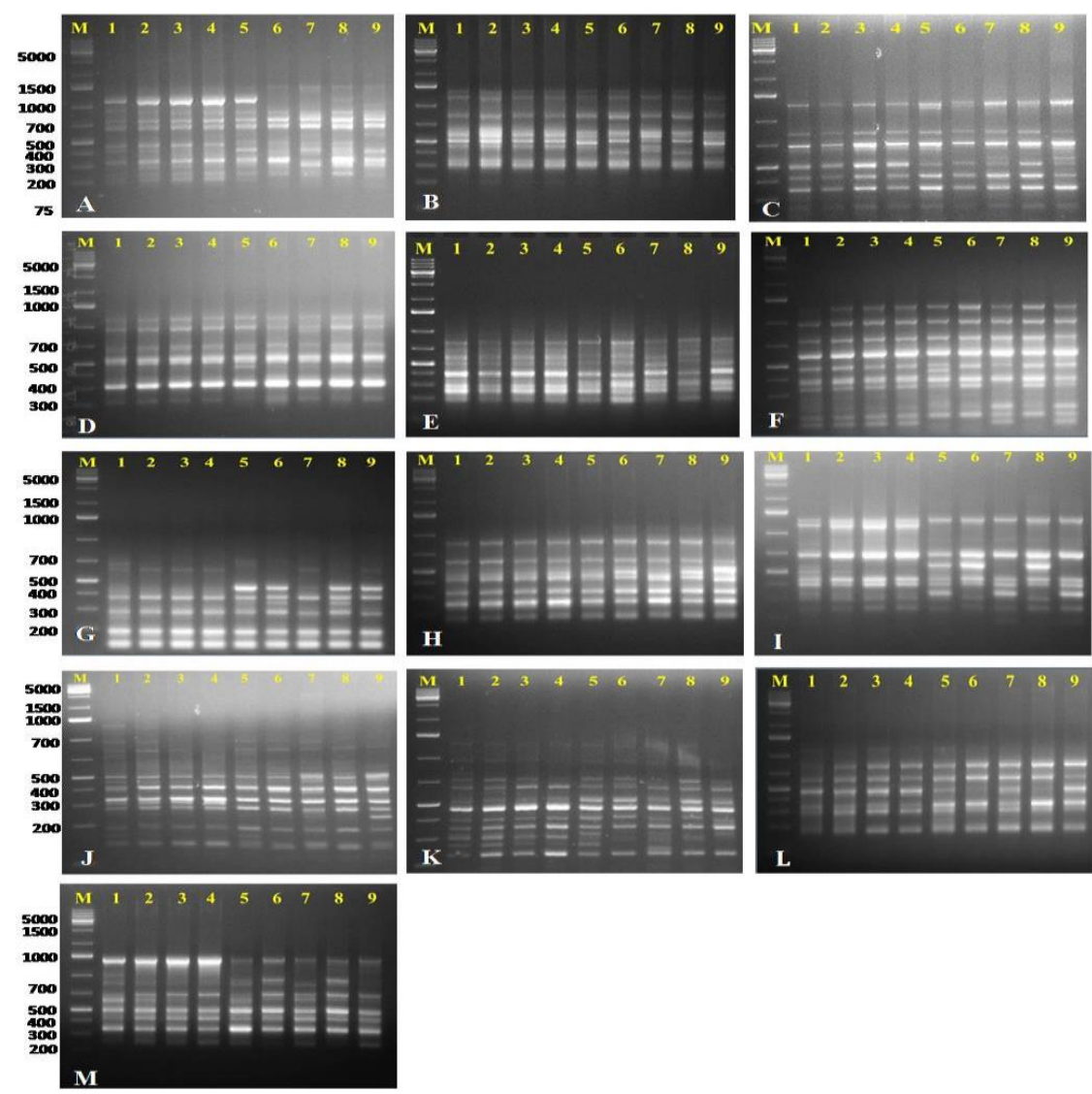

Fig. 1. Electrophoresis separation patterns of ISS R-PCR products (as revealed on $1.8 \%$ agarose gel) using primers P2 (A), P3 (B), P4 (C), P11 (D), P16 (E), H12 (F), H13 (G), H14 (H), H15 (I), H16 (J), H17 (K), H21 (L) and H29 (M). Lane M: $1 \mathrm{~Kb}$ plus DNA ladder marker. Lanes 1 to 9 represented Moshtohor grapefruit and pummelo genotypes: Ruby red, White, Duncan, Marsh, Broad leaf, Egyptian, Rabehe, Gizawy and Moneybi, respectively. 
All the tested primers produced polymorphic bands (Table 4) of the total 150 scorable fragments, 86 were polymorphic among the accessions (Fig. 1). The number of polymorphic bands ranged from 2 to 13 fragments resulting in an average of polymorphis $\mathrm{m} /$ primer (6.6). Primer $\mathrm{H}_{16}$ revealed the highest number of polymorphic bands (13). However, the lowest number of polymorphic amplicons (2) was generated by the $\mathrm{H}_{21}$ primer. The percentage of polymorphism revealed by different primers ranged from 29 to $83 \%$ with an average of $54.9 \%$.

TABLE 4. Total number of amplicons, monomorphic amplicons, polymorphic amplicons and percentage of polymorphism as revealed by ISS R markers among the 9 grape fruit and pummelo accessions collected from Moshtohor region.

\begin{tabular}{|l|c|c|c|c|}
\hline Primer & $\begin{array}{c}\text { Total } \\
\text { amplicons }\end{array}$ & $\begin{array}{c}\text { Monomorphic } \\
\text { amplicons }\end{array}$ & $\begin{array}{c}\text { Polymorphic } \\
\text { amplicons }\end{array}$ & $\begin{array}{c}\text { Percentages } \\
\text { of polymorphism }\end{array}$ \\
\hline $\mathrm{P}_{2}$ & 12 & 2 & 10 & 83 \\
\hline $\mathrm{P}_{3}$ & 11 & 4 & 7 & 64 \\
\hline $\mathrm{P}_{4}$ & 12 & 6 & 6 & 50 \\
\hline $\mathrm{P}_{11}$ & 9 & 4 & 5 & 56 \\
\hline $\mathrm{P}_{16}$ & 9 & 6 & 3 & 33 \\
\hline $\mathrm{H}_{12}$ & 11 & 7 & 4 & 36 \\
\hline $\mathrm{H}_{13}$ & 10 & 5 & 5 & 50 \\
\hline $\mathrm{H}_{14}$ & 14 & 5 & 9 & 64 \\
\hline $\mathrm{H}_{15}$ & 13 & 5 & 8 & 62 \\
\hline $\mathrm{H}_{16}$ & 18 & 5 & 13 & 72 \\
\hline $\mathrm{H}_{17}$ & 14 & 5 & 9 & 64 \\
\hline $\mathrm{H}_{21}$ & 7 & 5 & 2 & 29 \\
\hline $\mathrm{H}_{29}$ & 10 & 5 & 5 & 50 \\
\hline Total & 150 & 64 & 86 & 54.9 \\
\hline Average & 11.5 & 4.9 & 6.6 & \\
\hline
\end{tabular}

\section{Clustering analysis}

The UPGMA cluster analysis declared the degree of phylogenies among the different local pummelo accessions in comparis on with exotic grapefruit genotypes (Fig. 2). Phylogenetic analysis showed a high degree of genetic overlapping among the tested accessions, which reflected the intensive genetic relationships between different grapefruit and pummelo germplasm. The dendrogram analysis ranked Egyptian local pummelo accessions into two separated clusters at $81 \%$ level of similarity, the first included Moneybi and Rabehe genotypes however, other pummelo accessions were grouped with introduced grapefruit genotypes in the second cluster. Gizawe, Egyptian and Broad leaf pummelo acces sions were grouped in one lineage at $85 \%$ level of similarity. Conversely, different genotypes of grapefruit were gathered together in one cluster at $87 \%$ level of similarity. The highest genetic similarity was detected between Gizawe and Egyptian genotypes of pummelo germplasm as well as Duncan and White genotypes of grapefruit germplasm with $95 \%$ level of similarity. On the other hand, the highest genetic difference was identified between the accession grapefruit Ruby red and Moneybi pummelo genotype with a $78 \%$ level of similarity. 


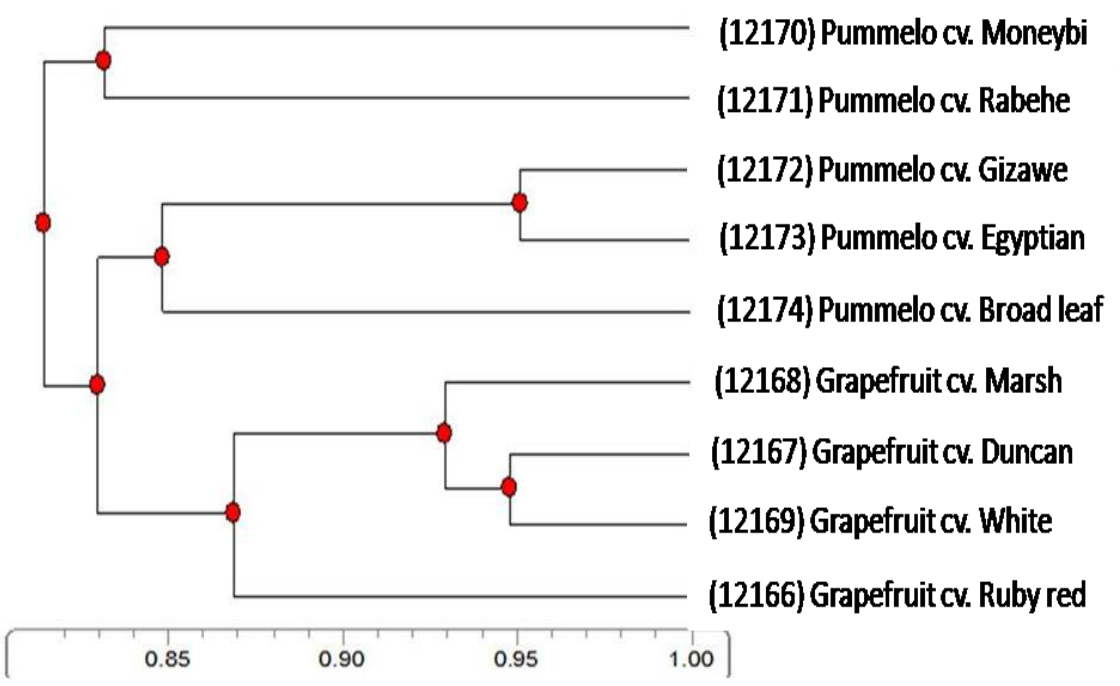

Fig. 2. Dendrogram for the 9 Grape fruit and Pummello genotype accessions (collected from Moshtohor region) constructed from the ISSR generated data using the UPGMA method and similarity matrices computed according to the Dice's similarity coefficient.

Genotype identification by unique ISSR markers

Despite the high genetic similarities among pummelo and grapefruit genotypes, genotype- specific ISSR unique markers were able to differentiate among 3 pummelo accessions (Broad leaf, Rabehe and Moneybi) as well as 3 grapefruit accessions (Ruby red, White and Marsh) out of the 9 tested accessions. The ISSR markers generated by primers and the positive and/or negative markers approximate size are shown in Table 5. Out of all tested ISSR primers, 11 primers were able to generate unique markers (positive and/ or negative) that could differentiate pummelo and grapefruit accessions. However, 2 primers $\left(\mathrm{H}_{14}\right.$ and $\left.\mathrm{H}_{21}\right)$ were failed to produce any unique markers. The number of generated unique markers in Broad leaf, Rabehe and Moneybi genotype`s of pummelo were 4, 6 and 7, respectively. However, the number of generated unique markers in Ruby red, White and Marsh grapefruit were 9,1 and 2, respectively.

Intra-variation within each citrus group

Grapefruit is the fourth economically most important Citrus fruit in the world (Uzun et al., 2010). A high level of genetic similarity was detected among grapefruit accessions ranging from 0.85 to 0.95 , this narrow genetic base among the grapefruit cultivars has been reported in previous publications using different molecular markers (Fang et al., 1997, Corazza-Nunes et al., 2002). The high level of similarity within the grapefruit group supported the hypothesis that the majority

Egypt. J. Hort. Vol. 42, No.1 (2015) 
of grapefruit cultivars were derived from the same ancestral tree by mutations (Gmitter, 1995). Pummelo has played an important role as a parent of many Citrus fruits, such as lemons, oranges and grapefruits. Among the five pummelo accessions, the genetic similarity ranged from a 0.85 to 0.95 this is in line with other published reports (Corazza-Nunes et al., 2002 and Uzun et al., 2010).

TABLE 5. Grapefruit and pummelo genotypes (collected from Moshtohor region) characterized by unique positive and/or negative IS S R markers, marker size and total number of ISS R markers identifying each genotype.

\begin{tabular}{|c|c|c|c|c|c|c|}
\hline \multirow{2}{*}{ Accessions } & \multirow{2}{*}{ Primer } & \multicolumn{2}{|c|}{ Unique positive } & \multicolumn{2}{|c|}{ Unique negative } & \multirow{2}{*}{ Total } \\
\hline & & Size in bp & Total & Size in bp & Total & \\
\hline \multirow{7}{*}{12166 (Ruby red) } & H13 & 254 & 1 & - & - & \multirow{7}{*}{9} \\
\hline & H16 & 164,1330 & 2 & 419 & 1 & \\
\hline & H17 & 793 & 1 & - & - & \\
\hline & $\mathrm{H} 29$ & 1000 & 1 & - & - & \\
\hline & $\mathrm{P} 2$ & - & - & 257 & 1 & \\
\hline & $\mathrm{P} 4$ & - & - & 715 & 1 & \\
\hline & P11 & 706 & 1 & - & - & \\
\hline 12169 (White) & P3 & 195 & 1 & - & - & 1 \\
\hline \multirow{2}{*}{12168 (Marsh) } & H16 & - & - & 852 & 1 & \multirow{2}{*}{2} \\
\hline & P3 & - & - & 616 & 1 & \\
\hline \multirow{4}{*}{$\begin{array}{l}12174 \text { (Broad } \\
\text { leaf) }\end{array}$} & $\mathrm{H} 12$ & 448 & 1 & - & - & \multirow{4}{*}{4} \\
\hline & H16 & 781 & 1 & - & - & \\
\hline & $\mathrm{P} 4$ & 1266 & 1 & - & - & \\
\hline & P11 & 239 & 1 & - & - & \\
\hline \multirow{6}{*}{12171 (Rabehe) } & H12 & - & - & 333 & 1 & \multirow{6}{*}{6} \\
\hline & H15 & 177 & 1 & - & - & \\
\hline & H17 & - & - & 742 & 1 & \\
\hline & P3 & 1361 & 1 & - & - & \\
\hline & P11 & 886 & 1 & - & - & \\
\hline & P16 & 326 & 1 & - & - & \\
\hline \multirow{5}{*}{12170 (Moneybi) } & H15 & - & - & 294 & 1 & \multirow{5}{*}{7} \\
\hline & H17 & - & - & $\begin{array}{l}973,132 \\
8\end{array}$ & 2 & \\
\hline & $\mathrm{P} 2$ & 588 & 1 & 482 & 1 & \\
\hline & $\mathrm{P} 4$ & 463 & 1 & - & - & \\
\hline & P16 & - & 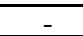 & 586 & 1 & \\
\hline
\end{tabular}

\section{Morphological characterization}

Quantitative characteristics

Table 6 presents leaves and flowers quantitative traits of the grapefruits and pummelo germplasm under the present investigation. Results showed that [12166, 12168 and 12170] accessions exhibited the highest leaf lamina length (cm) of 12.80, 12.70 and $13.00 \mathrm{~cm}$, respectively. The lowest leaf length was presented by grapefruit accessions number $12169(10.28 \mathrm{~cm})$. The rest of the germplasm showed intermediate values of leaf length. Accession number 12166 showed the greatest leaf lamina width $(6.43 \mathrm{~cm})$. However, there was no significant difference among the accessions number [12167, 12168, 12170, 12171, 1272, 12173 and 12174], respectively. The lowest leaf width value obtained by accession number 12169 was (4.28). The uppermost ratio of 
leaf lamina shape (length/ width ratio) was 2.52, 2.50 and $2.40 \mathrm{~cm}$ for the accession numbers [12167, 12168 and 12169], respectively. The pummelo accession number 12171 was [2.18], accession number 12170 gave (2.16) and accession number 12174 gave (2.21). The lowest ratio was characterized by grapefruit accession number 12166 was 1.99, Pummelo accessions number 12172 and 12173 (Table 6). The accession numbers 12166, 12167, 12172, 12173 and 12174 showed the highest value of flower pedicle length i.e. 1.81, $2.10,2.05,2.18$ and $2.00 \mathrm{~cm}$, respectively. The lowest ones $(0.90$ and $1.00 \mathrm{~cm})$ were exhibited by the accession numbers 12168 and 12171, respectively. Whereas the rest of the germplasm illustrated intermediate values. Accessions number 12166 grapefruit, 12170 and 12171 pummelo germplasm showed five petals per flower whereas, the rest of the germplasm showed four petals per flower (Table 6). The petal length was different among the cultivars, where accessions number (12174) Pummelo gave $(2.64 \mathrm{~cm})$ presented the highest measurements followed by grapefruit accession number 12166 as it was $(2.45$ $\mathrm{cm})$. Concerning Pummelo accession numbers [12170, 12171 and 12173] there were no significant difference among them. The lowest petal length was presented by grapefruits accessions number [12168 and 12169] as they gave $(1.75 \mathrm{~cm}$ and $1.69 \mathrm{~cm})$, respectively. On the other hand, there was no significant difference between grapefruit and pummelo germplasm of petal width (Table 6).

TABLE 6. Morphology quantitative characteristics of leaves and flowers of nine grapefruits and pummelo germplasm grown in Egypt.

\begin{tabular}{|c|c|c|c|c|c|c|c|c|c|c|c|c|c|c|}
\hline $\begin{array}{l}\text { Acces } \\
\text { sions }\end{array}$ & \multicolumn{2}{|c|}{$\begin{array}{c}\text { Leaf } \\
\text { length } \\
(\mathrm{cm})\end{array}$} & \multicolumn{2}{|c|}{$\begin{array}{c}\text { Leaf } \\
\text { width } \\
(\mathrm{cm})\end{array}$} & \multicolumn{2}{|c|}{$\begin{array}{c}\text { Leaf } \\
\text { ratio } \\
\text { L/w }\end{array}$} & \multicolumn{2}{|c|}{$\begin{array}{c}\text { Flower } \\
\text { pedicel } \\
\text { length } \\
(\mathrm{cm})\end{array}$} & \multicolumn{2}{|c|}{$\begin{array}{l}\text { Number } \\
\text { of petals }\end{array}$} & \multicolumn{2}{|c|}{$\begin{array}{l}\text { Petal } \\
\text { length } \\
(\mathrm{cm})\end{array}$} & \multicolumn{2}{|c|}{$\begin{array}{c}\text { Petal } \\
\text { width } \\
(\mathrm{cm})\end{array}$} \\
\hline \multicolumn{15}{|c|}{ Grapefruit } \\
\hline 12166 & 12.80 & $\mathrm{a}$ & 6.43 & $\mathrm{a}$ & 1.99 & $\mathrm{~b}$ & 1.81 & $\mathrm{a}$ & 5 & $\overline{\mathrm{A}}$ & 2.45 & $\overline{a b}$ & 1.10 & $\mathrm{a}$ \\
\hline 12167 & 12.00 & $\mathrm{ab}$ & 4.75 & $a b$ & 2.52 & $\mathrm{a}$ & 2.10 & $\mathrm{a}$ & 4 & B & 2.22 & $\mathrm{~b}$ & 0.84 & $\mathrm{a}$ \\
\hline 12168 & 12.70 & $\mathrm{a}$ & 5.08 & $a b$ & 2.50 & $\mathrm{a}$ & 0.90 & $\mathrm{c}$ & 4 & B & 1.75 & $\mathrm{c}$ & 0.75 & $\mathrm{a}$ \\
\hline 12169 & 10.28 & $\mathrm{~b}$ & 4.28 & $\mathrm{~b}$ & 2.40 & $\mathrm{a}$ & 1.40 & $\mathrm{~b}$ & 4 & B & 1.69 & $\mathrm{c}$ & 0.77 & $\mathrm{a}$ \\
\hline \multicolumn{15}{|c|}{ Pummelo } \\
\hline 12170 & 13.00 & $\mathrm{a}$ & 6.00 & $a b$ & 2.16 & $a b$ & 1.20 & $\mathrm{bc}$ & 5 & A & 2.40 & $a b$ & 0.74 & $\mathrm{a}$ \\
\hline 12171 & 12.14 & $a b$ & 5.57 & $a b$ & 2.18 & $a b$ & 1.00 & $\mathrm{c}$ & 5 & $\mathrm{~A}$ & 2.60 & $a b$ & 0.74 & $\mathrm{a}$ \\
\hline 12172 & 11.70 & $\mathrm{ab}$ & 6.10 & $a b$ & 1.92 & $\mathrm{~b}$ & 2.05 & $\mathrm{a}$ & 4 & $\bar{B}$ & 2.24 & $\mathrm{~b}$ & 0.97 & $\mathrm{a}$ \\
\hline 12173 & 11.75 & $a b$ & 5.88 & $a b$ & 1.99 & $\mathrm{~b}$ & 2.18 & $\mathrm{a}$ & 4 & B & 2.33 & $a b$ & 0.92 & $\mathrm{a}$ \\
\hline 12174 & 11.13 & $a b$ & 5.03 & $a b$ & 2.21 & $a b$ & 2.00 & $\mathrm{a}$ & 4 & B & 2.64 & $\mathrm{a}$ & 0.97 & $\mathrm{a}$ \\
\hline C.V\% & \multicolumn{2}{|c|}{8.37} & \multicolumn{2}{|c|}{18.32} & \multicolumn{2}{|c|}{9.06} & \multicolumn{2}{|c|}{12.30} & \multicolumn{2}{|c|}{10.00} & \multicolumn{2}{|c|}{8.86} & \multicolumn{2}{|c|}{12.08} \\
\hline
\end{tabular}

Values have the same letter(s) in the same column are not significantly different at $\mathrm{LSD} \leq 0.05$ level

Egypt. J. Hort. Vol. 42, No.1 (2015) 
The quantitative characteristics of fruits and seeds are demonstrated in (Table 7). Pummelo accession number 12170 showed the highest significant fruit weight $(1140.09 \mathrm{~g})$ followed by pummelo accession number $12171(996.1 \mathrm{~g})$.

On the other hand, grapefruit accession number 12168 had the lowest fruit weight $(351.5 \mathrm{~g})$. The rest of the germplasm gave intermediate fruit weights (Table 7). Although pummelo accession number 12170 exhibited the greatest fruit diameter $(14.25 \mathrm{~cm})$, followed by pummelo accession number 12173 which was $(13.20 \mathrm{~cm})$. The grapefruit accessions number $(12166,12168$ and 12169) displayed the lowest fruit diameter $(9.00,9.00$ and $9.33 \mathrm{~cm})$, respectively. The remaining germplasm had intermediate values ranged from $(10.40-12.7 \mathrm{~cm})$. The last fruit length was demonstrated by the grapefruit accession number $12167(13.20 \mathrm{~cm})$. However, no significant differences were obtained as compared with the pummelo accessions number $12170(11.50 \mathrm{~cm})$, accession number $12171(11.25 \mathrm{~cm})$ and accession number $12174(11.21 \mathrm{~cm})$. Meanwhile, grapefruit accession number 12166 showed the lowest value of fruit length (7.20 $\mathrm{cm})$. The rest of the germplasm gave an intermediate fruit length (Table 7).

The fruit thickness indicates that the grapefruits accessions number 12167 and pummelo accessions number 12170 had the greatest fruit rind thickness $(1.85$ and $2.00 \mathrm{~cm})$. Conversely, the grapefruit accession number 12166 and 12168 had intermediate fruit rind thickness. However, no significant differences obtained as compared with the germplasm grapefruit accession number 12169 $(0.50 \mathrm{~cm})$, pummelo accession number (12171, 12172, 12173 and 12174) (Table 7). The amount of juice content (ml/fruit) was different among germplasm. The greatest was $415.0 \mathrm{ml}$ in the pummelo accession number 12171 followed by the accession number $12172(383.0 \mathrm{ml})$. The least juice content was obtained from the grapefruit $12166(135.0 \mathrm{ml})$ whereas, the rest of the germplasm showed intermediate juice amount (Table 7).

The pummelo accession number 12170 proved the highest significant seed length value ranging $(2.25 \mathrm{~cm})$, whereas the pummelo accession number 12173 was the least seed length $(1.08 \mathrm{~cm})$. Although the accessions number 12171, 12172 and 12174 showed intermediate seed length values as it was no significant differences compared with the pummelo accession number 12170. Similarly, grapefruit accessions number 12166, 12167, 12168 and 12169 showed no significant differences in comparison with the pummelo accession number 12170 (Table 7). Seed width from all accessions had no significant differences between grapefruits and pummelo germplasm.

Table 7 indicates that the pummelo accession number 12170 had the greatest average seed weight $(0.65 \mathrm{~g})$ followed by the grapefruit accession number $12169(0.31 \mathrm{~g})$. The rest of the germplasm exhibited intermediate average seed weight values. It had no significant differences in comparison with pummelo accession number 12170 . 
It is concluded that pummelo acces sion number 12170 has the best quantitative traits as proved by the highest fruit weight, diameter, length, rind thickness, and juice content, as well as the high seed length, width and weight.

TABLE 7. Morphology quantitative characteristics of fruit and seed of nine grapefruits and pummelo germplasm grown in Egypt.

\begin{tabular}{|c|c|c|c|c|c|c|c|c|c|c|c|c|c|c|c|c|}
\hline \multirow[t]{2}{*}{ Accession } & \multicolumn{2}{|c|}{$\begin{array}{c}\text { Fruit } \\
\text { weight } \\
\text { (g) }\end{array}$} & \multicolumn{2}{|c|}{$\begin{array}{c}\text { Fruit } \\
\text { diameter } \\
\text { (cm) }\end{array}$} & \multicolumn{2}{|c|}{$\begin{array}{l}\text { Fruit } \\
\text { length } \\
\text { (cm) }\end{array}$} & \multicolumn{2}{|c|}{$\begin{array}{c}\text { Fruit } \\
\text { rind } \\
\text { thickness } \\
(\mathrm{cm})\end{array}$} & \multicolumn{2}{|c|}{$\begin{array}{l}\text { Juice } \\
\text { content } \\
\text { (ml/fruit) }\end{array}$} & \multicolumn{2}{|c|}{\begin{tabular}{|c|} 
Seed \\
length \\
$(\mathrm{cm})$
\end{tabular}} & \multicolumn{2}{|c|}{\begin{tabular}{|c|} 
Seed \\
Width \\
(cm)
\end{tabular}} & \multicolumn{2}{|c|}{$\begin{array}{c}\text { Seed } \\
\text { Weight } \\
\text { (g) }\end{array}$} \\
\hline & & & & & & & \multicolumn{10}{|c|}{ Grapefruit } \\
\hline 12166 & 401.22 & $\mathrm{f}$ & 9.00 & $\mathrm{f}$ & 8.20 & $\bar{d}$ & 0.90 & $\mathrm{~b}$ & 135.0 & $\mathrm{~h}$ & 1.30 & $\mathrm{bc}$ & 1.00 & $\mathrm{a}$ & 0.22 & $\mathrm{~b}$ \\
\hline 12167 & 380.6 & $\mathrm{~g}$ & 8.80 & g & 8.50 & $\mathrm{u}$ & 1.85 & & 145.0 & $\mathrm{~g}$ & 1.48 & $\mathrm{~b}$ & 0.74 & & 0.28 & $\mathrm{~b}$ \\
\hline 12168 & 351.5 & $\mathrm{~h}$ & 9.00 & f & 8.33 & d & 0.60 & bc & 165.0 & f & 1.33 & $\mathrm{bc}$ & $\mid 0.87$ & & 0.21 & $\mathrm{~b}$ \\
\hline 12169 & 414.0 & $\mathrm{f}$ & 9.33 & $f$ & 8.06 & d & 0.50 & & 152.0 & fg & 1.36 & $\mathrm{bc}$ & 0.90 & a & 0.31 & $a b$ \\
\hline \multicolumn{17}{|c|}{ Pummelo } \\
\hline 12170 & 1140.0 & $\mathrm{a}$ & 14.25 & $\mathrm{a}$ & 13.20 & $\mathrm{a}$ & 2.00 & $\mathrm{a}$ & 415.0 & $\mathrm{a}$ & 2.25 & $\mathrm{a}$ & 1.02 & $\mathrm{a}$ & 0.65 & $\mathrm{a}$ \\
\hline 12171 & 996.1 & $\mathrm{~b}$ & 12.25 & c & 11.25 & b & 0.50 & & 264.0 & d & 1.40 & $\mathrm{bc}$ & 0.75 & $\mathrm{a}$ & 0.22 & $\mathrm{~b}$ \\
\hline 12172 & 862.5 & e & 11.40 & d & 10.60 & c & 0.50 & $c$ & 383.0 & b & 1.30 & bc & 0.80 & $\mathrm{a}$ & 0.25 & $\mathrm{~b}$ \\
\hline 12173 & 977.5 & c & 13.20 & b & 10.80 & $\mathrm{c}$ & 0.50 & $\mathrm{c}$ & 313.0 & $\mathrm{c}$ & 1.08 & $\mathrm{c}$ & 0.80 & $\mathrm{a}$ & 0.24 & b \\
\hline 12174 & 904.0 & $\bar{d}$ & 10.40 & e & 11.21 & b & 0.40 & $\mathrm{c}$ & 227.0 & $\mathrm{e}$ & 1.52 & $\mathrm{~b}$ & 0.77 & a & 0.22 & B \\
\hline$\overline{C . V \%}$ & 1.40 & & 1.77 & & 1.95 & & 13.2 & & 4.29 & & & & 13. & & & 23 \\
\hline
\end{tabular}

Values have the same letter(s) in the same column are not significantly different at $\mathrm{LSD} \leq 0.05$ level .

\section{Qualitative characteristics}

Table 8 presents the qualitative traits of fruit, seed and leaf of the nine grapefruits and pummelo germplasm under the present study. In this regard, only the grapefruit accession number 12167 showed pyriform fruit shape. While, the accessions number 12166, 12170, and 12173 showed obloid fruit shape. The rest of the germplasm showed spheroid fruit shape.

The fruit skin colour included 12 colour ranged from green to red-orange. The grapefruit accession number 12166 had pink-yellow fruit skin colour. While accessions number 12167 and 12170 were green-yellow. Only the pummelo accession number 12172 had dark-yellow. The rest of the germplasm showed yellow fruit skin colour. The pummelo accession no. 12173 was the only one showed pitted texture of skin surface. The cultivars Ruby red, White, Moneybi, Gizawe and Broad leaf proved rough skin surface texture, whereas grapefruits Duncan cv., Marsh and pummelo Rabehe CV. Showed smooth surface skin texture (Table 8).

Egypt. J. Hort. Vol. 42, No.1 (2015) 
The flesh colour presented in (Fig. 3 and Table 8) red colour of fruit flesh was clear in the grapefruit Ruby red cultivar and pummelo broad leaf cultivar only, where as it was yellow in grapefruit Duncan, Marsh and pummelo Gizawe cultivars. Meanwhile, pummelo Moneybi showed pink fruit flesh while the rest of the germplasm showed white colour of fruit flesh. The classifications, under which products of the fruit hub of the diverse cultivars were assessed where solid, semi-hollow and hollow fruit axis. The cultivars grapefruit Ruby red and pummelo Broad leaf demonstrated semi-hollow while, pummelo Moneybi and Rabehe cultivars indicated hollow fruit axis. Whatever is left of the germplasm indicated solid fruit axis (Table 8). Only the Ruby red cultivar showed concave shape of fruit base. The germplasm Duncan and Gizawe revealed necked fruit base shape. On the other hand, pummelo Moneybi and Rabehe cultivars showed hollow fruit axis. The rest of the germplasm showed solid fruit axis (Table 8). The Ruby red cultivar fruit base was concave in shape, but Duncan and Gizawe germplasm were necked fruit base shape. On the other hand, pummelo Moneybi and Rabehe accessions showed convex fruit shape of base. The accessions exhibited truncate fruit base shape (Table 8). Regarding fruit apex shape, 12168 CV. showed rounded fruit apex shape whereas, Ruby red, Duncan and pummelo broad leaf accessions demonstrated truncate. The remaining of the accessions displayed depressed shape of fruit apex.

TABLE 8. Performance of different grapefruit and pummelo germplasm regarding fruit shape, fruit skin colour, fruit axis, fruit shape of base and fruit shape of apex.

\begin{tabular}{|l|c|c|c|c|c|c|c|}
\hline Accession & $\begin{array}{c}\text { Fruit } \\
\text { shape }\end{array}$ & $\begin{array}{c}\text { Fruit skin } \\
\text { colour }\end{array}$ & $\begin{array}{c}\text { Skin } \\
\text { texture }\end{array}$ & $\begin{array}{c}\text { Flesh } \\
\text { colour }\end{array}$ & $\begin{array}{c}\text { Fruit } \\
\text { axis }\end{array}$ & $\begin{array}{c}\text { Fruit } \\
\text { shape of } \\
\text { base }\end{array}$ & $\begin{array}{c}\text { Fruit } \\
\text { shape of } \\
\text { apex }\end{array}$ \\
\hline \multicolumn{7}{|c|}{ Grapefruit } \\
\hline 12166 & Obloid & Pink-yellow & Rough & Light red & $\begin{array}{c}\text { Semi- } \\
\text { hollow }\end{array}$ & Concave & Truncate \\
\hline 12167 & Pyriform & Green-yellow & Smooth & Yellow & Solid & Necked & Truncate \\
\hline 12168 & spheroid & Yellow & Smooth & Yellow & Solid & Truncate & Rounded \\
\hline 12169 & spheroid & yellow & Rough & White & Solid & Truncate & Truncate \\
\hline 12170 & Obloid & Green-yellow & Rough & Pink & Hollow & Convex & Depressed \\
\hline 12171 & spheroid & Yellow & Smooth & White & Hollow & Convex & Depressed \\
\hline 12172 & spheroid & Dark-yellow & Rough & Light & Solid & Necked & Depressed \\
& & & & Yellow & & & \\
\hline 12173 & obloid & Yellow & Pitted & White & Solid & Truncate & Depressed \\
\hline 12174 & spheroid & Yellow & Rough & Red & $\begin{array}{c}\text { Semi- } \\
\text { hollow }\end{array}$ & Truncate & Truncate \\
& & & & & &
\end{tabular}

Egypt. J. Hort. Vol. 42, No.1 (2015) 


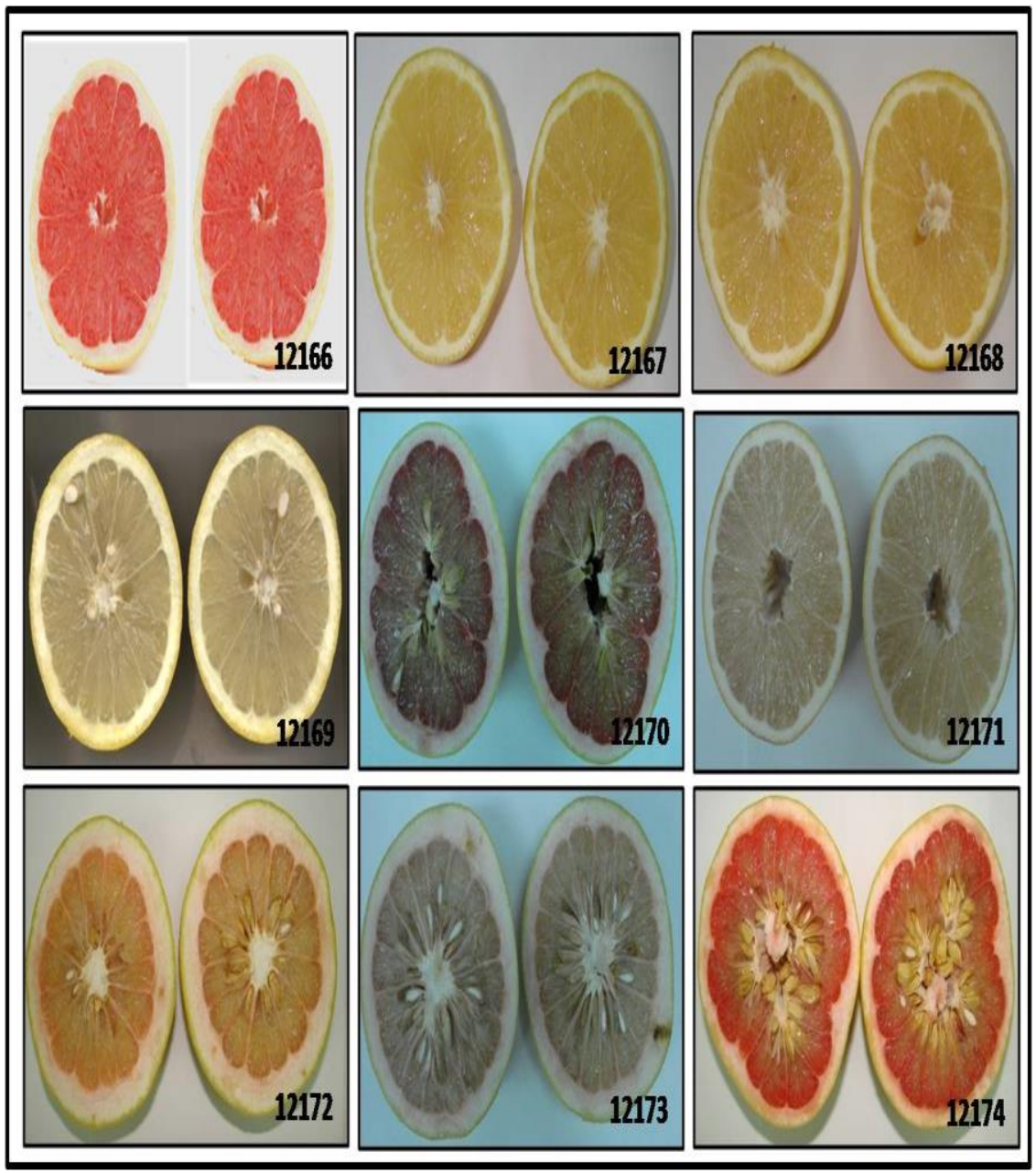

Fig. 3. Fruits cross section of four grapefruit accessions number from (12166) to (12169) and five pummelo accessions number from (12170) to (12174) collected from Egypt.

Table 9 illustrates the no. of segment per fruit (10-14) for accessions no. (12166, 12167, 12168, 12169 and 12171). While, the rest of the accessions had 15-18 segment/fruit. The qualitative characteristics of no. of seed/fruit, seed shape, seed surface, leaf lamina shape and petiole wings shape are presented in Table 9. The average no. of seed/fruit was generally high in most of the germplasm tested. The highest counted number of seeds/fruit $(>50)$ was evident in the accessions no. 12170 and 12171. The accessions no. 12172 and 12173 showed (20-50) seeds/fruit. While, pummelo accession no. 12174 had (10-19) seeds/fruit. Only grapefruit accession no. 12169 had (1-4) seeds/fruit. The rest of the accessions had (5-9) seeds/fruit.

Egypt. J. Hort. Vol. 42, No.1 (2015) 
TABLE 9. Quantitative characteristics of grapefruit and pummelo germplasm.

\begin{tabular}{|l|c|c|l|l|c|l|}
\hline Accession & $\begin{array}{c}\text { No. of } \\
\text { segment }\end{array}$ & $\begin{array}{c}\text { No. of } \\
\text { seed/fruit }\end{array}$ & \multicolumn{1}{|c|}{$\begin{array}{c}\text { Seed } \\
\text { shape }\end{array}$} & $\begin{array}{c}\text { Seed } \\
\text { surface }\end{array}$ & $\begin{array}{c}\text { Leaf } \\
\text { lamina } \\
\text { shape }\end{array}$ & $\begin{array}{c}\text { Petiole } \\
\text { wings } \\
\text { shape }\end{array}$ \\
\hline \multicolumn{7}{|c|}{ Grapefruit } \\
\hline 12166 & $10-14$ & $5-9$ & Ovoid & Smooth & Ovate & Obdeltate \\
\hline 12167 & $10-14$ & $5-9$ & $\begin{array}{l}\text { Semi- } \\
\text { deltoid }\end{array}$ & wrinkled & Elliptic & Absent \\
\hline 12168 & $10-14$ & $5-9$ & $\begin{array}{l}\text { Semi- } \\
\text { deltoid }\end{array}$ & wrinkled & Ovate & obcordate \\
\hline 12179 & $10-14$ & $1-4$ & $\begin{array}{l}\text { Semi- } \\
\text { deltoid }\end{array}$ & wrinkled & Elliptic & Obdeltate \\
\hline \multicolumn{7}{|c|}{ Pummelo } \\
\hline 12171 & $15-18$ & $>50$ & $\begin{array}{l}\text { Semi- } \\
\text { spheroid }\end{array}$ & wrinkled & Elliptic & obcordate \\
\hline 12172 & $10-14$ & $>50$ & ovoid & Smooth & Orbicular & obcordate \\
\hline 12174 & $15-18$ & $20-50$ & $\begin{array}{l}\text { Semi- } \\
\text { spheroid }\end{array}$ & wrinkled & Ovate & obcordate \\
& $15-18$ & $20-50$ & $\begin{array}{l}\text { Semi- } \\
\text { deltoid }\end{array}$ & Smooth & Ovate & obcordate \\
\hline
\end{tabular}

The grapefruit accession no. 12166 and pummelo accession no. 12171 were presented ovoid seed shapes. Just two germplasm specifically Moneybi and Gizawe showed semi-spheroid seed shape (Table 9). Seed shape of the rest of the cultivars $(56 \%)$ was semi- deltoid. Among the studied cultivars, the Ruby red, Rabehe, Egyptian and Broad leaf demonstrated smooth seed surface the residues of the germplas $m$ had wrinkled seed shape. The investigation of leaf lamina shape included elliptic, ovate, obviate. lanceolate, orbicular and obcordate. None of the investigated cultivars under the present study indicated obovate, lanceolate or obcordate leaf lamina shape. Three only accessions number (12167, 12169 and 12170) exhibited elliptic leaf shape. However, pummelo accession no. 12171 showed orbicular leaf shape. The rest of the germplasm displayed ovate leaf lamina shape (Table 9). The absence or presence of petiole wings were evaluated for the different cultivars (Table 9). The grapefruit accession no. 12167 demonstrated absent petiole wings whereas those of the rest of the germplasm were present. One only accession had obovate petiole wings shape while, the grapefruit accession no. 12166 and 12169 exhibited obdeltate petiole wings shape. On the other hand, the rest of the germplasm showed obcordate.

Morphological characterization of grapefruit and pummelo was studied by several researchers (Uzun et al., 2010) they found that the variation of fruit weight was more or less similar to thos studied by (Ara et al., 2008 and Samarasinghe, 2005). In contrast (Mitra et al., 2011) obtained more wide range of fruit weight (570-2010 g). Although number of seeds per fruit is almost similar to that of present findings. Present finding showed significant variation of number of seeds per fruit (20-50) to $(>50)$. With less number of seeds was obtained in Type-9 and Type-12 but Hazarika (2013) obtained less number of seeds (12.67-37.50) among all the twelve collections of pummelo at Mizoram. 
Dendrogram of pomological relationship (cluster analysis).

The UPGMA Dendrogram obtained with 28 qualitative and quantitative measurements for the 9 grapefruit and pummelo accessions are shown in Fig 4 . The accessions were clustered into two main groups. Group1 included five accessions that could be divided into two subgroups (1A and 1B). Generally, the accessions in this group had large fruit size. Only pummelo cultivar "Moneybi" with pink flesh colour and higher fruit weight (1140 g) was in subgroup 1B. The subgroup 1A consisted of four accessions of which "Rabehe" and "Egyptian" had similar fruit size and flesh colour and the genetic distance was (5-8). On the other hand, Group 2 consisted of 4 accessions and separated into two subgroups (2A and $2 \mathrm{~B}$ ) based on different morphological characteristics such as fruit weight, diameter, length, rind thickness, juice content, seed length, seed width and seed weight. Subgroup 2B which included one cultivar namely "Marsh" had rounded fruit shape of apex while, subgroup 2A consisted 3 accessions of which "Ruby red", "White" and "Duncan". But, "Duncan" and "White" cultivars showed very similar fruit characters the genetic distance was (3-6). The accessions in this group had small fruit weigh.

\section{Morphological distance}

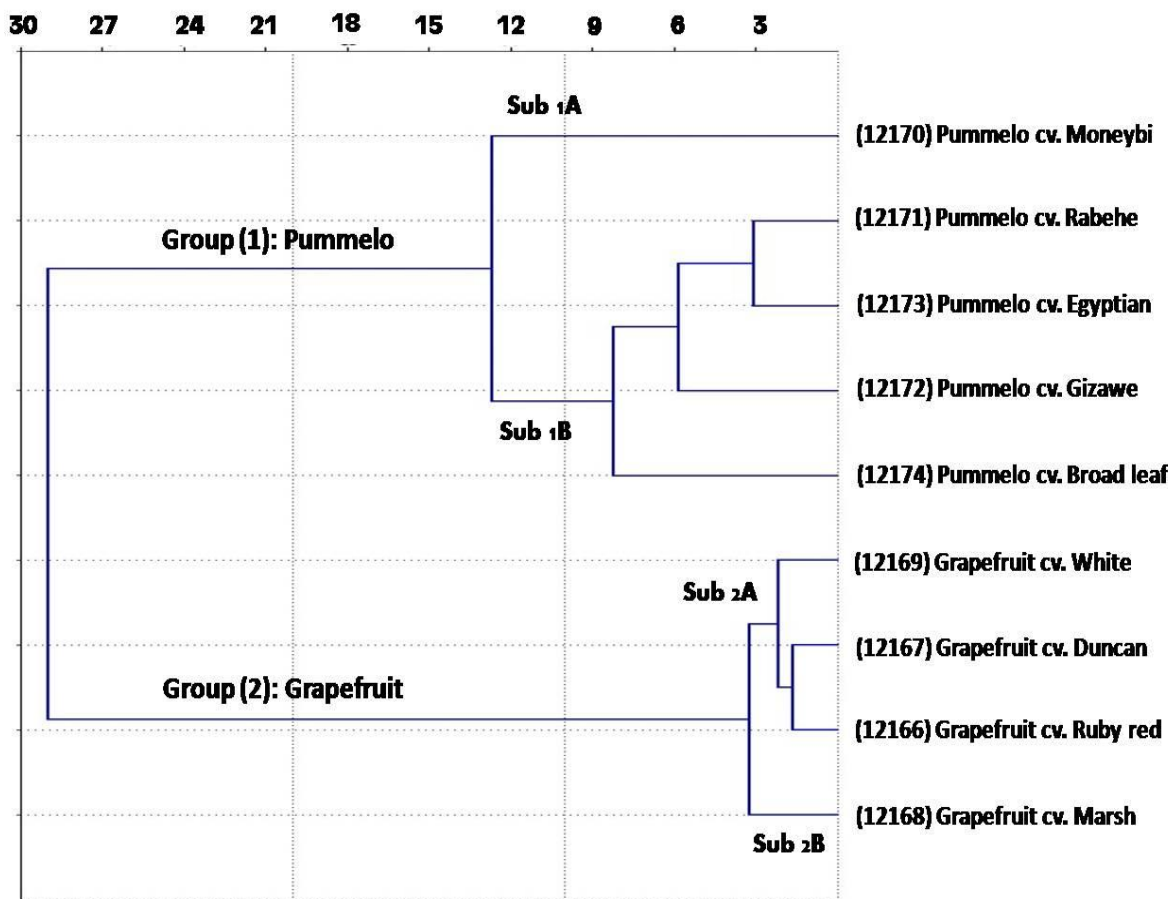

Fig. 4. UPGMA Dendrogram using the Manhattan distances based on morphopomological distances of grapefruits and pummelo accessions sampled from qalyubia governorate, Egypt.

Egypt. J. Hort. Vol. 42, No.1 (2015) 
In conclusion, in order to preserve the property rights of the genetic diversity of local citrus varieties in Egypt, there is an urgent need to collect additional samples of all local citrus varieties. In our study grapefruit and pummel varieties from other governorates and locations are to be targeted by conducting collection missions. In this connection, Citrus germplasm in all of Egypt regions are to be focused on to ensure that most of the genetic diversity has been captured and conserved ex situ and should go towards local verities registration. Morphological and molecular characterization will facilitate the identification of duplicate germplasm and in selecting the core collection for long term conservation.

\section{References}

Ara, N., Bashar, M.K., Uddin, M.K. and Khalequzzaman, K.M. (2008) Evaluation of pummelo, Citrus grandis L. cultivars in northern area of Bangladesh. J. Agric. Res., 46, 65-75.

Barkley, N.A., Roose, M.L., Krueger, R.R. and Federici, C.T. (2006) Assessing genetic diversity and population structure in a citrus germplasm collection utilizing simple sequence repeat markers (SSRs). Theor. Appl. Genet., 112, 1519-1531.

Barrett, H.C. and Rhodes, A.M. (1976) A numerical taxonomic study of affinity relationships in cultivated Citrus and its close relatives. Systematic Botany, 1, 105-136.

Corazza-Nunes, MJ., Machado, MA., Nunes, WMC., Cristofani, M. and Targon, M.L.P.N. (2002) Assessment of genetic variability in grapefruits (Citrus paradisi) and pummelos (C.maxima) using RAPD and SSR markers. Euphytica, 126, 169-176.

Fang, DQ., Roose, M.L. Krueger, R.R. and Federici, C.T. (1997) Fingerprinting trifoliate orange germplasm accession with isozymes, RFLPs, and inter-simple sequence repeat markers. Theor. Appl. Genet., 95, 211-219.

Fang, D.Q., Krueger, R.R. and Roose, M.L. (1998) Phylogenetic relationships among selected Citrus germplasm accessions revealed by inter-simple sequence repeat (ISSR) markers. J. Amer. Soc. Hortic., 123, 612-617

FAOS TAT (2012) Food and Agricultural Organization of the United Nations, http://faostat.fao.org./fileadmin/templates/est/COMM_MARKETS_MONI TORING/ Citrus/Documents/Citrus_BULLETIN_2012.pdf.

Federici, C.T., Fang, D.Q., Scora, R.W. and Roose, M.L. (1998) Phylogenetic relationships within the genus Citrus, Rutaceae and related genera as revealed by RFLP and RAPD analy sis. Theor. Appl. Genet., 96, 812-822.

Gmitter, F.G. (1995) Origin, evolution and breeding of the grapefruit. Plant Breed. Rev., 13, 345-363.

Hazarika, T.K., Lalbiakngheti, M. and Nautiyal, B.P. (2013) Genetic variability in physico-chemical characteristics of some pummelo collections from Mizoram. Indian J. Hort., 70, 431-34. 
IPGRI (1999) Descriptors for Citrus. International Plant Genetic Resources Institute, Rome, Italy. ISBN 92-9043-425-2.

Kahn, T.L., Krueger, R.R., Gumpf, D.J., Roose, M.L., Arpaia, M.L., Batkin, T.A., Bash, J.A., Bier, O.J., Clegg, M.T. and Cockerham, S.T. (2001) Citrus genetic resources in California: Analysis and recommendations for long-term conservation. Report no.22. Univ. of Calif. Division of Agric. and Natural Resources, Genetic Resources Conservation Program, Davis, CA, USA.

Kumar, M., Parthiban,S.,SaralaDevi, D. and Ponnuswami, V. (2013) Genetic diversity analy sis of acid lime (Citrus aurantifolia Swingle) cultivarrs. The Bioscan. 8 (2), 481 - 484.

Lowe, A., Stephen, H. and Ashton, P. (2004) Ecological Genetics: Design, Analysis, and Application, Blackwell Publishing) pp. 6-100.

Ministry of Agriculture (2013) Agriculture Statistics Bulletin, Egypt.

Mitra, S.K., Maity, C.S., Ghosh, B.and Pathak, P.K. (2011) Genetic resources of pummelo (Citrus grandis Osbeck) in West Bengal, India. Acta Hort., 918, 667-71.

Nicolosi, E., ZN. Deng, A. Gentile, S. La Malfa, G. Continella and E. Tribulato (2000) Citrus phylogeny and genetic origin of important species as investigated by molecular markers. Theor. and Appl. Genetics, 100, 1155-1166.

S amarasinghe, P.W.S.M.(2005) Selection and conservation of good quality pummelo (Citrus grandis L.) mother trees. IPGRI Newsletter for Asia, Pacific and Oceania, 47, 21-22.

Scora, R.W. (1988) Biochemistry, taxonomy and evolution of modern cultivated Citrus. Proc. Int. Soc. Citricult. VI. Congr. vol. 1. Margraf Publishers, Weikersheim, Germany, pp. 277-289.

Scora, R.W., Kumamoto, J., Soost, R.K. and Nauer, E.M. (1982) Contribution to the origin of the grapefruit, Citrus paradisi (Rutaceae). Syst. Bot., 7, 170-177.

Singh, B.D. (2005) Plant Breeding: Principles and Methods, Kalyani Publishers) pp. 1 -434.

Sneath, P.H.A. and Sokal, R.B. (1973) Numerical taxonomy. The principles and practice of numerical classification. San Francisco: W. H. Freeman.

Uzun, A. and Yesiloglu, T. (2012) Genetic diversity in citrus. Scientia Horticulturae 11, 213-230.

Uzun, A., Gulsen, O., Yesiloglu, T., Aka-Kacar, Y. and Tuzcu, O. (2010) Distinguishing grapefruit and pummelo accessions using ISSR markers. Czech $J$. Genet. Plant Breed., 46, 170-177.

Uzun, A., T. Yesiloglu, Y. Aka-Kacar, O. Tuzcu and O. Gulsen (2009). Genetic diversity and relationships within Citrus and related genera based on sequence related amplified polymorphism markers (SRAPs). Scientia Horti., 121, 306-312.

Vinu, V., Singh, N., Vasudev, S., Yadava, DK., Kumar, S., Naresh, S., Bhat, S.R. and Prabhu, K.V. (2013) Assessment of genetic diversity in Brassica juncea (Brassicaceae) genotypes using phenotypic differences and SSR markers. Rev. Biol. Trop., 61 (4), 1919-1934.

Egypt. J. Hort. Vol. 42, No.1 (2015) 
Yong, L., De-Chun, L., Bo, W. and Zhong-Hai, S. (2006) Genetic diversity of pummelo (Citrus grandis Osbeck) and its relatives based on simple sequence repeat markers. Chinese J. Agr. Biotechnology, 3, 119-126.

(Received 22/9/2014;

\title{
التوصيف المورفولوجى و الجزيئي باستخدام تقية ISSR فى I الجريب فروت و الثنادوك
}

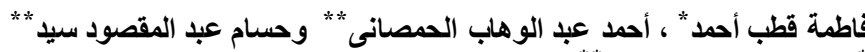

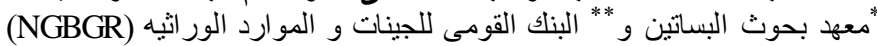

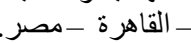

\begin{abstract}
تتضمن المهام القومية للبنك القومي للجينات و الموارد الوراثية بجمهورية مصر الزئية

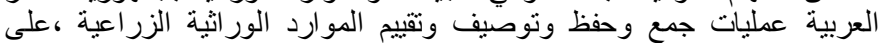

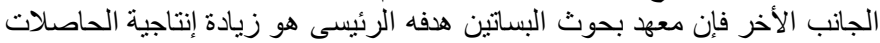

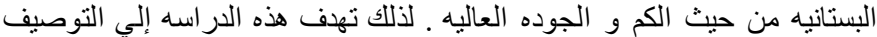

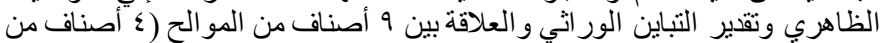

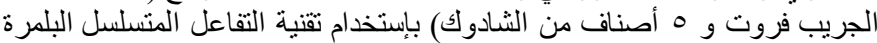

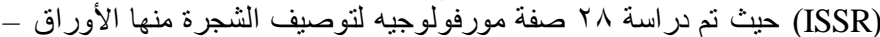

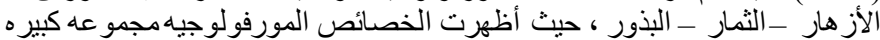

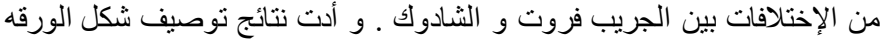

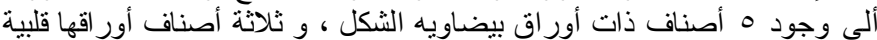

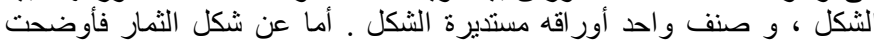

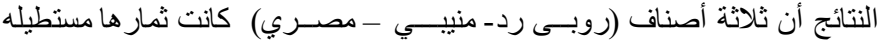

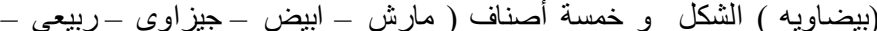

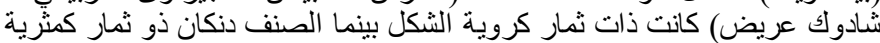

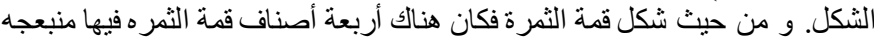

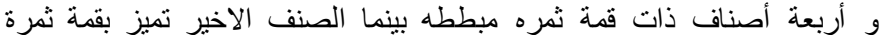

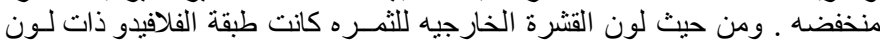

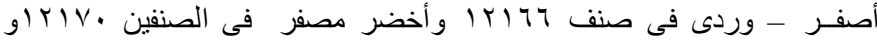

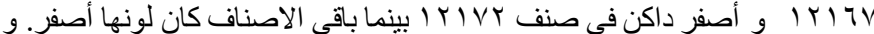
كان لون اللحم (لب الثرة) أبيض في الاصنفاف

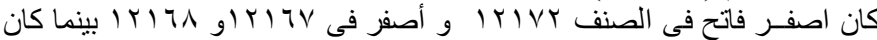

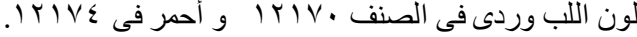

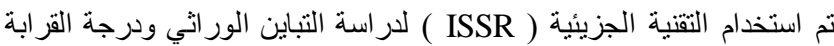

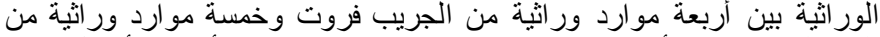
الثادوك حيث تم أختبار عدد ثناثة عشر بارئ بادئ

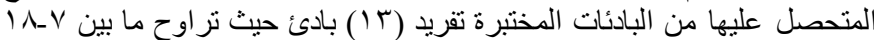

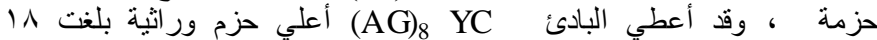

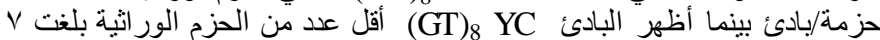

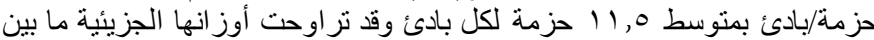

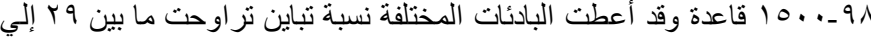

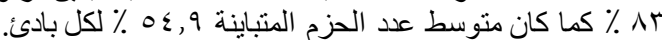

